\title{
Chemical and Physical Characteristics of Beef and Vegetarian (Veggie) Burger Served in Some Hotels
}

\author{
Neven Sherif Abd.El Haleam 1
}

\begin{abstract}
Tourism industry considered as one of the fundamental economic recourses, hotels must focus on customer requirements.

Customer demand for veggie burgers has been increased rapidly. Chemical and physical characteristics of beef and veggie burgers were evaluated, based on chemical composition, dietary fiber, Minerals, amino acids contents, color and sensory evaluation. The results showed lower moisture content $(\mathbf{4 2 . 9 \%})$ in beef burgers than veggie burgers $(\mathbf{5 0 . 9 9 \%})$. Curd protein contents in beef burgers was $37.87 \%$ while it was $16.88 \%$ in veggie burgers. Minerals contents were high in veggie burger comparing with the beef burger. Also veggie burgers had higher value of Neutral detergent fiber NDF $(\mathbf{2 2 . 8 4 \%})$ than beef burger $(17.96 \%)$. Statistical analysis of sensory evaluation found a significant differences $(\mathrm{P}<0.01)$ between beef and veggie burgers in color and taste.
\end{abstract}

\section{INTRODUCTION}

Tourism industry considered as one of the fundamental economic resources, it is a generator for a large amount of income for many countries. (Ingold, A. and Yeomon, I. 2003)

Hospitality and food service play a substantial role in providing this income. Thus hotels must be viewed as profit centers focusing on customer requirements. (Latliny, 2000). Customer demand for beef burgers has been increased rapidly, so many efforts have been made to improve the quality of beef burgers. (Papadina and Bloukas, 1999). Since red meats are a good source of high biological value protein (clay, 2004). However, as reported by (El. Zalaki, 2001) red meats form the nutritional point of view are rich source of animal fats that contain high amount of triglycerides of saturated fatty acids as well as cholesterol.

That is why vegetarianism was having a strong popularity, with an estimated 15 million practitioners in the united states (Messina et al, 2003). Vegetarian eating patterns are three types: Vegans eats vegetables and fruits, avoid dairy products and eggs. Ovovegetarians eats the same type one but added eggs to their meals. Lacto- vegetarians the same type one but they eat egg and dairy products (Bond, 2000). Also vegetarians have a lower intake of cardiovascular disease, there for many customer preferred to eat vegetarian food, veggie

${ }^{1}$ High Institute of Tourism and Hotels (EGOTH)

Received August 3, 2009, Accepted September 14, 2009 burgers one of this food which means a meatless patty made of ground grains and vegetables (Nulty, 2001). The objective of study was to evaluate the chemical and physical characteristics of beef and veggie burgers.

\section{MATERIALS AND METHODS}

\subsection{Burger manufacture}

2.1.1. Ingredients of beef burgers and veggie burgers

Ingredients of beef burgers and veggie burgers were 10 $\mathrm{g}$ finely chopped onion, $1 \mathrm{~g}$ minced garlic, $350 \mathrm{~g}$ beef meat, $50 \mathrm{~g}$ chopped green bell pepper, $20 \mathrm{~g}$ shredded carrot, $1 / 2 \mathrm{~L}$ chicken soup, $30 \mathrm{~g}$ flour, $0.5 \mathrm{~g}$ shredded parsley, $1 / 4 \mathrm{~L}$ sun flower oil, and for veggie burgers were the same ingredients of beef burgers but $350 \mathrm{~g}$ meat has been replaced with $125 \mathrm{~g}$ Finally chopped mushroom., $125 \mathrm{~g}$ boil lentil and $100 \mathrm{~g}$ cooked rice.

\subsubsection{Preparing and cooking beef burgers and veggie} burgers

The oil was heated in a skillet over low heat and the onion and garlic were cooked for about five minutes until tender then they were mixed with meat, green pepper, parsley, carrot and chicken soup. Continue to cook and stirring for two minutes, then skillet was removed from heat and the mixture was transferred to a bowl and shaped into eight $1 / 2$ inch thick patties, the flour was placed on a large plate, each patty was dropped into the flour. Oil was put in a skillet for high heat and the patties were fried for 3 minutes each side. Veggie burgers were prepared using the same mentioned method which used in preparing beef burgers but replaced meat with mushroom, lentil and rice, when mixing the contents.

\subsection{Burger analysis}

\subsubsection{Proximate composition}

Moisture, ash, crud protein, ether extract, crude fiber and carbohydrate, and mineral content were determined by A.O.A.C. methods (A.O.A.C., 1999).

Amino acids was calculated according the FAO/WHO (1991) method which based on the amino acid pattern of egg as reference protein and amino acid score was calculated as follows:

amino acid score $=\frac{\mathrm{g} \text { of amino acid in test protein sample }}{\mathrm{g} \text { of amino acid of } \mathrm{FAO} / \text { who reference protein }}$ 


\subsubsection{Dietary fiber content}

Dietary fiber was determined by the method of (Van Soest et al, 1991). They were calculated as follows:

Neutral Detergent Fiber

$(\mathrm{NDF})=\frac{\left(\mathrm{W}_{\mathrm{o}}-\mathrm{W}_{\mathrm{t}}\right)}{\mathrm{S}} * 100$

where: $\mathrm{W}_{\mathrm{O}}$ = weight of oven - dry crucible including fiber

$\mathrm{W}_{\mathrm{t}}$ = weight of oven - dry crucible including fiber

$\mathrm{S} \quad=$ sample weight

Acid Detergent Fiber

$(\mathrm{A} D \mathrm{~F})=\frac{\left(\mathrm{W}_{\mathrm{O}}-\mathrm{W}_{\mathrm{t}}\right)}{\mathrm{S}} * 100$

where $: \mathrm{W}_{\mathrm{O}}$ = weight of oven - dry crucible including fiber

$$
\begin{aligned}
\mathrm{W}_{\mathrm{t}} & =\text { Tared weight of oven }- \text { dry crucible } \\
\mathrm{S} & =\text { sample weight }
\end{aligned}
$$

The insoluble hemicellulose content was calculated by difference using the following equation :

$\mathrm{HC}=\mathrm{NDF}-\mathrm{ADF}$

\subsubsection{Color determination :}

Color was measured at the surface of cooked burgers using Lovibond Tintometer model E, made by tintometer LTD, England.

\subsubsection{Sensory Evaluation}

Sensory evaluation of different properties (color, odor, taste, appearance and overall quality) was conducted by ten trained panelists using composite scoring test according to (Meilgard et al, 1999).

\subsection{Statistical Method}

Statistical analysis to sensory data were used to calculate means, standard deviations to determine significant difference $(\mathrm{P}>0.01)$ between pairs of samples which fulfils the requirements according to
(British standards, 1986). The data were analysed using the SPSS statistical package program.

\section{RESULTS AND DISCUSSIONS}

The data in table (1) indicates the proximate composition of beef and veggie burgers. The results show that beef burgers had lower moisture content $(42.9 \%)$ than veggie burgers $(50.99 \%)$. According to Hassan (2002) the moisture in mushroom was high (65\%), also Abd El. Hady (1998) found that moisture in Egyptian rice was $(13.5 \%)$, also legume proteins have an important property viz the ability to bend water (Reitmeier and Prusa, 1991).

The crude protein contents of beef burgers were $(37.87 \%)$ and decreased in veggie burgers to $16.88 \%$. Similar results were reported by Candogan (2002) for beef patties with added tomato paste. Also, the results are in good agrement with Anderson and Berry ( 2001) for high-fat ground beef with inner pea fiber. Ether extract in beef burgers were $33.81 \%$, it decreased in veggie burgers to $25.67 \%$, this could be attributed to fat absorption during frying however still veggie burgers had less content of fat. Same result reported by Muschiolik et al (1994) for highest gain in fat on frying the beef burgers. Ash contents in beef and veggie burgers were $6.13 \%$ and $4.04 \%$ on dry base respectively. Crude fiber for beef and veggie burger were $0.55 \%$ and $0.71 \%$, respectively and this might due to the content of beef and veggie burgers. Turhan (2005) reported similar results when added 1-2\% hazelnut Pellicle in the low fat beef burger production as a dietary fibre source. The carbohydrate content was lower in the beef burgers $(21.48 \%)$ then in the veggie burgers $(52.80 \%)$ and this variation might due to the mushroom, lentil and rice in veggie burger.

Dietary fiber intake is associated with the preparation of several disorders of the human body including diveticular diseases and cancer of the colon, constipation, coromary heart diseases, diabetes and other diseases of the gastrointestinal tract (Lazarow and Werman, 1996).

Table1. Proximate composition of beef and veggie burgers

\begin{tabular}{lcccc}
\hline \multicolumn{1}{c}{$\begin{array}{c}\text { Component } \\
(\%)\end{array}$} & \multicolumn{2}{c}{ Beef Burger } & \multicolumn{2}{c}{ Veggie Burger } \\
\cline { 2 - 5 } & W.B. ${ }^{*}$ & D.B. & W.B. & D.B. \\
\hline Moisture & 42.91 & - & 50.99 & - \\
Crude Protein & 21.62 & 37.87 & 8.29 & 16.88 \\
Ether Extract & 19.98 & 33.81 & 12.58 & 25.67 \\
Ash & 3.62 & 6.13 & 1.98 & 4.04 \\
Crude Fiber & 0.42 & 0.55 & 0.27 & 0.71 \\
Carbohydrate \# (NFE) & 11.45 & 21.64 & 25.89 & 52.70 \\
\hline
\end{tabular}

* Wet base

- Dry base

\# By difference 
Table (2) shows the dietary fiber content of the beef and veggie burger. A remarkable variation was found between the two kinds of burgers in neutral detergent fiber (NDF). Veggie burger had higher value of NDF $(22.84 \%)$ than beef burger (17.96\%) (on dry base).

A slight variation was found in acid detergent fiber (ADF) between beef and veggie burger (1.44\% and $1.33 \%$, respectively). Also the veggie burger had higher amount of hemicellulose (HC) $(21.51 \%)$ than beef burger $(16.52 \%)$, on dry base.

Similar results were obtained by Crehan et al (2000), Pietrasik and Duda (2000) for burger with inner pea fiber, soy protein and cattagenan.

Minerals elements content of beef and veggie burgers are shown in table (3). The results indicated that there was slight variation between beef and veggie burger in potassium ( 350 and $380 \mathrm{mg} / \mathrm{g}$, respectively) and sodium ( 210 and $220 \mathrm{mg} / \mathrm{g}$, respectively). Also, the results revealed that the veggie burger contained the higher level of Magnesium, Calcium and Iron (756.94, 85.164 and $110.961 \mathrm{mg} / \mathrm{g}$, respectively) comparing with beef burger (511.28, 60.075 and $100.67 \mathrm{mg} / \mathrm{g}$, respectively). And this might due to ingredients of veggie burger.

Amino acids contents is considered one of the most important factor which gives valuable information about nutritional value of protein (Piskarev, 1991) amino acids content of beef and veggie burgers were shown in table (4) the amino acids of the investigated burgers protein was compared with the reference pattern reported by FAO/WHO. The results indicate that the amino acids contents of two different kinds of burgers were varied as compared with those of FAO/WHO pattern. It could be observed that beef and veggie burgers had almost the same level of lysine (6.2 and $6.25 \mathrm{~g} / 100 \mathrm{~g}$ protein). However, that level were higher as compared with the FAO/WHO pattern $(5.5 \mathrm{~g} / 100 \mathrm{~g}$ protein). Also Methionine and cystine level of beef burgers $(5.1 \mathrm{~g} / 100 \mathrm{~g}$ protein) are higher than FAO/WHO pattern $(3.5 \mathrm{~g} / 100 \mathrm{~g}$ protein) and that on the contrary in veggie burgers $(1.74 \mathrm{~g} / 100 \mathrm{~g}$ protein). Moreover phenylalanine and tyrosine level of beef burgers $(8.3 \mathrm{~g} / 100 \mathrm{~g}$ protein) are higher than $\mathrm{FAO} / \mathrm{WHO}$ pattern $(6.0 \mathrm{~g} / 100 \mathrm{~g}$ protein) but lower in veggie burgers (4.79 $\mathrm{g} / 100 \mathrm{~g}$ protein).

Color of many food are important quality attributes in restaurants, they related to consumer preferences based on the appearance of the meal (Ninemier, 1999). Color values aestmated by Lovibond tintometer is shown in table (5), beef burgers had the higher values for yellow, while veggie burgers had high value for red color. Lovibond values were transformed to IE system according to (Ranggana, 1999). It was noticed that the dominant wavelength (hue) was $553 \mathrm{~nm}$ for beef burgers and $573 \mathrm{~nm}$ for veggie burger, this means that beef burger is yellowish green in color and veggie burgers was greenish yellow, Yilmaz (2003) obtained similar results in meatball samples with rye bran added, yellowness value showed the similar trend. More over the beef burgers had higher purity and brightness values (0.72-84.14, respectively) while the veggie burgers had (0.16-78.52, respectively) this might due to the meatless in the formulation of veggie burgers and the ether extract in beef burgers which approximately $33 \%$.

Table 2. Dietary fiber of beef and veggie burgers

\begin{tabular}{lcccc}
\hline \multicolumn{1}{c}{ Component } & \multicolumn{2}{c}{ Beef Burger } & \multicolumn{2}{c}{ Veggie Burger } \\
\cline { 2 - 5 }$(\%)$ & W.B. * & D.B. ${ }^{\bullet}$ & W.B. & D.B. \\
\hline Neutral Detergent fiber (NDF) & 15.24 & 17.96 & 20.94 & 22.84 \\
Acid Detergent fiber (ADF) & 0.76 & 1.44 & 0.77 & 1.33 \\
Hemicellulose content (HC) & 14.48 & 16.52 & 20.17 & 21.51 \\
\hline
\end{tabular}

*Wet base

-Dry base

Table 3. Minerals content of beef and veggie burger

\begin{tabular}{|c|c|c|}
\hline Mineral (mg/g) & Beef Burger & Veggie Burger \\
\hline Potassium & 350 & 380 \\
\hline Sodium & 210 & 220 \\
\hline Magnesium & 511.28 & 756.94 \\
\hline Calcium & 60.075 & 85.164 \\
\hline Iron & 100.67 & 110.961 \\
\hline
\end{tabular}


Table 4. Amino acids content of fried beef and veggie burgers (g/100 g protein)

Amino Acid Beef burgers Veggie Burgers FAO/WHO pattern (g/100 g protein)

\begin{tabular}{lccc}
\hline Isoleucine & 5.00 & 3.65 & 4.0 \\
Leucine & 7.70 & 3.48 & 7.0 \\
Lysine & 6.20 & 6.25 & 5.5 \\
Therionine & 5.40 & 2.92 & 4.0 \\
Valine & 3.60 & 2.08 & 5.0 \\
Methionine & 5.1 & 1.74 & 3.5 \\
Cystine & & & \\
Phenyl alanine & 8.3 & 4.79 & 6.0 \\
Tyrosine & 7.70 & 3.08 & - \\
Agrinine & 2.95 & 1.83 & 1.4 \\
Histidine & & & \\
\hline
\end{tabular}

Table 5. Color values of beef and veggie burger estimated using Lovebond

\begin{tabular}{lllllll}
\hline Sample & yellow & red & blue & hue & purity & brightness \\
\hline Beef burger & 21.1 & 11.1 & 0.1 & 553 & 0.72 & 84.14 \\
Veggie burger & 0.8 & 7.6 & 0.9 & 573 & 0.162 & 78.52 \\
\hline
\end{tabular}

Consumer acceptance is a complex process in which perceived information from foods is integrated during tasting. While instrumental testing provides useful information, the complexity of the changes due to formulation in samples in relation to acceptance could only be perceived by discrimination and consumer tasting (Kennedy et al, 2004; Lauwless and Heymann, 1999; Macfie and Hedderley, 1993). Table (6) shows the means value and standard deviation of color, oder, taste, appearance and overall quality for both beef and veggie burgers, it observed that only color and taste of beef burgers had significant differences $(\mathrm{P}<0.01)$ between beef and veggie burgers. On the other hand no significant differences were observed $(\mathrm{P}>0.01)$ between beef and veggie burgers regarding to oder, appearance and overall quality, this results agree with Torrescano et al (2003) using lycopene rich tomato and peppers as a source of antioxidants.

Table (6): Statistical analysis of sensory evaluation.

\begin{tabular}{lcc} 
Variety & Beef burger & Veggie burger \\
\hline Color & $8.4 \pm 1.17$ & $9.80 \pm 0.42$ \\
Odor & $8.30 \pm 1.16$ & $9.10 \pm 1.28$ \\
Taste & $8.70 \pm 0.67$ & $9.50 \pm 0.52$ \\
Appearance & $8.60 \pm 1.50$ & $9.20 \pm 0.63$ \\
Over all quality & $8.50 \pm 1.17$ & $9.10 \pm 0.56$ \\
\hline
\end{tabular}

\section{CONCLUSION}

The vegetarian burgers are acceptable in terms of sensory quality. And rich in neutral detergent fiber, acid detergent fiber and minerals such as magnesium, calcium and iron.

\section{REFERENCES}

Abd El. Hady, E.Y. (1998). Enzymatic production of high protein rice flour from Egyption broken rice Ph.D thesis, fac of Agric., univ. of Alex., Egypt.

AOAC. (1999). Official Methods of Analysis. AOAC International, Washington, DC.

Anderson, E. T. and Berry, B.W. (2001) effects of inner pea fiber on fat retention and cooking yield in high fat ground beef. Food Research International, 34, 689-694.

Bond, A. (2000). Vegetarian Vitality. The vegetarian society pub, uk.

British standards (1986). British standard method for sensory analysis of foods. British institution, London.

Candogan, k. (2002). The effect of tomato paste on some quality characteristics of beef patties during refrigerated storage. European food Research and technology, 215, 305-309.

Creahan, C. M., Hughes, E., troy, D.J. and Buckley D.J. (2000). Effects of fat level and maltodextrin on the functional properties of frankfurter formulated with 5, 12 and $30 \%$ fat. Meat science, $55: 463.469$.

El-Zalaki, E.M. (2001). Meat Technology Food Science and Technology Series- El Marif Modern Pub, Alex. (In Arabic).

FAO and WHO. (1991). Protein quality evaluation report of a joint FAO / WHO expert cultivation. FAO / WHO Rome, Italy.

Hassan, F. R. (2002). Studies on the bioconversion of same agricultural wastes using pleurotus and Agaricus mushrooms. Ph. D thesis, fac. Of Agric., univ. of Cairo, Egypt. 
Ingold, A. and Yeomon, I. (2003). Strategies for the Service Industeries. RE press, London.

Kennedy, O.; Stewart, B. ; Mitchell, P. and Thurnhan, D. (2004). The influence of context upon consumer sensory evaluation of chicken meat quality. British food journal, 106(3), 158-165.

Latlin, W.G. (2000). The lodging and food service industry. Educational institute of the American hotel and motel.

Lawless, H.T. and Heymann, H. (1999). Sensory evaluation of food principles and practices. Gaithersburg, MD, USA.

Lazarow, K. and Werman, M. J. (1996). Hypocholestroleamic effect of potato peel as a dietary fiber sources. Med. Sci. Res. 24 : 581-582.

Macfie, H.J. and Hedderley, D. (1993). Current practice in relating sensory perception to instrumental measurements. Food quality and preference, 4, 41-49.

Meilgard, M., Civille, G. and Carr, T. (1999). Sensory evaluation techniques. CRC press.

Messina, V.E., Melina, L. and Angles, A.R. (2003). A new food guide for American vegetarians. J. Am. Diet Assoc. 103; 771.5.

Muschiolik, G., Schmandke, H., zdziennicki, A. K. Rotkiewicz, D. and Borowsha, J (1994) Influence of conditions of extrusion on the suitability of fried bean protein raw materials as meat substituted in fried comminuted meat. Nahrung, 28(2), 133-140.

Ninemier, J. D. (1999). Planning and control for food and beverage operations. The educational institute of the American hotel and motel association, USA.

Nulty, M. (2001). Vegetarian burger. Taylor and francis ltd, London.
Papadina, S. N. and Bloukas, J. G. (1999). Effect of fat level and storage Conditions on quality characteristics of traditional Greek sausages. Meat Science. 51, 103-113.

Pietrasik, Z. and Duba, Z. (2000). Effect of fat content and soy protein, carrageman mix on the quality characteristics of comminuted scalded sausages. Meat science, 56, 181188.

Piskarev, A. T. (2001). Changes in free amino acid peptides during frozen meat. Food sci. and tech., 48 : 40-49.

Ranganna, S. (1999). Handbook of analysis and quality control for fruit and vegetable products. McGraw - Hill publishing, New Delhi.

Reitmier, C.A. and prusa, K.J. (1991). Composition, cooking loss, color and compression of ground pork with dry and wet-milled corn germ meals. J. of food science. 56, 216219.

Thuhan, S. (2005). Utilization of hazelnut pellicle in low-fat beef burgers. Meat science, 71, 312-316.

Torrescano, G. Djenane, D. and Beltran, J.A. (2003). Stabilization of Colour and adour of Beef Patties using Lycopene-rich Tomato and Peppers as a source of antioxidants J. of the Science of Food and Agr. , 83, 187194.

Van Soest, P. J., Rohertsoh. J. B., Lewis, B. A. (1991). Methods for dietary fiber and non starch polysaccharides in relation to animal nutrition. J. Dairy Sci. 74, 3583 3597

Yilmaz, I. (2003). Effect of rye bran addition on fatty acid composition and quality characteristics of low-fat meatballs. Meat science, $67: 245-249$. 


\section{الملنخص العربي}

\section{الخصائص الكيميائية والفيزيائية المميزة للبرجر البقري والنبايت المقدم في بعض الفنادق}

$$
\text { نيفين شريف عبد الحليم }
$$

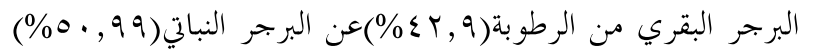
وكان تركيز البروتين في البرجر البقري

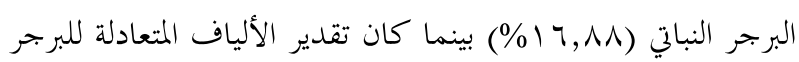

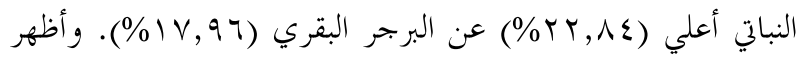

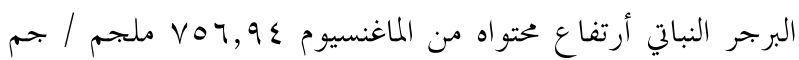
والحديد الج9, ، 1 الملجم/جم. و كذلك أظهر التحليل الإحصائي للاختبار الحسي وجود فروق معنوية بين البرجر البقري والنباتي في اللون و الطعم وتقبل المستهلك للبرجر النباتي.
تعد السياحة أحد المصادر الأساسية للدخل القومي، ولابد

للفنادق والمطاعم أن تركز علي احتياجات العميل من الأغذية حيث

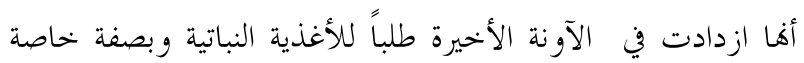
البرجر النباتي. استهدفت الدراسة تقييم الصفات والخصائص المميزة للبرجر البقري والنباتي من خلال إجراء التحليل الكيميائي وتقدير الألياف المتعادلة والألياف المقاومة للأحماض ومحتوي البرجر من المعادن والأحماض الأمينية وكذلك قياس اللون وإجراء تقييم وتحليل إحصائي للاختبار الحسي. وقد أوضحت النتائج انخفاض محتوي 